GLOBAL JOURNAL OF SOCIAL SCIENCES VOL 16, 2017: 9-15

COPYRIGHT@ BACHUDO SCIENCE CO. LTD PRINTED IN NIGERIA. ISSN 1596-6216

www.globaljournalseries.com; Info@globaljournalseries.com

\title{
ENTREPRENEURSHIP OPPORTUNITIES IN SOCIAL AND MANAGEMENT SCIENCES: MAKING SUSTAINABLE LIVING THROUGH FREELANCE SALESMANSHIP SERVICE
}

ALFRED J. M. EDEMA, MARYJOAN UGBOAKU IHEANACHO AND EKPE OYONO EKPE

(Received 15, March 2017; Revision Accepted 24, August 2017)

\begin{abstract}
The whole idea about entrepreneurship is to create self-employment and job for others. Today, much of the thinking about entrepreneurship skill development revolves more around the production of goods and plays down on selling and marketing. Most people, particularly young graduates for some reasons have perceived entrepreneurial undertaking with respect to selling as a difficult stride to achieve. This has added to the numerous problems befalling entrepreneurship skill learning. This conceptual paper situates entrepreneurship opportunities in social and management sciences within the service offer of freelance salesmanship. The Thesis is that graduates of social and management sciences are readily self-employable if properly orientated in the skills of selling. Even more to it, they are agents of job creation. Raising this consciousness among academics and students particularly becomes necessary because, again, the major problem of most manufacturing and service-providing organizations is not creating a job, rather, there is no money to pay salaries and allowances to those who may be engaged on the job due to lack of sales.
\end{abstract}

KEYWORDS: Entrepreneurship opportunities, selling, environment, self-employment, occupation, selfrealization.

\section{INTRODUCTION}

Government at the three basic levels federal, state and local, institutions, commercial and non-commercial organizations as well as well-meaning philanthropic individuals are concerned about how to get the Nigerian graduate gainfully employed. The cardinal goal is to reduce youth unemployment, societal vices, and fulfilling one of the core objectives of education. To hypothesize that entrepreneurship is a new educational concept amounts to fallacy. One can therefore, argue in favour of the crusade for this supposed new thinking at a different level of learning, more seriously in tertiary institutions and especially in the university system as one way of adding a new program product or at least, a course to enhance the learning curriculum. This is premised on past learning experiences at primary education level, talking from the 1950s through the $60 \mathrm{~s}$ and some part of the $70 \mathrm{~s}$. This kind of learning orientation was true for pupils in the primary, and even in the then modern schools. At that period, children were made to get engaged in handiwork or craft productions. Their psychomotor education (El-Sayed et al., 2010; Uwaifo, 2010; Okwelle, 2013) centered around traditional occupations and includes the making of brooms in bunches, basket weaving, mat weaving, artistic carving, wrapper/cloth weaving and dying, bead making, palm kernel cream/oil, and lots more. Implicitly, the children have started getting involved in business because, again, some of them produced beyond

Alfred J. M. Edema, Department of Business Management, University of Calabar, Calabar, Cross River State, Nigeria.

Maryjoan Ugboaku Iheanacho, Department of Business Management, University of Calabar, Calabar, Cross River State, Nigeria.

Ekpe Oyono Ekpe, Department of Business Management, University of Calabar, Calabar, Cross River State, Nigeria. 
just what was required to meet with school assignments and so, they could give the surplus to their mothers to sell for them during major village market days, while others themselves, go hawking their products. No doubt, they (children) grew up and passed out of the school with these skills. Thus, entrepreneurship became necessary if not compulsory, thoughtful household menu, aligning with school curriculum.

Today, modern thinking and the application of tools and machines in creating and innovating products (technology), have tremendously made the inroads into entrepreneurship skill development far different and enriching. Thus, much of the thinking about entrepreneurship skill concerns with the production of goods and plays down on selling and marketing. This has added to the numerous problems befalling entrepreneurship skill learning. The whole idea about entrepreneurship is about self-employment (Duru, 2011). Hypothetically, most people, particularly young graduates for some reasons have perceived entrepreneurial undertaking with respect to selling as a difficult stride to achieve. First, they see it from a wrong view that it is meant for those who cannot get white collar jobs; second, there is huge financial (capital) requirement; third, is the unfortunate inability to identify self-worth; forth, is the thought of how to start and where to start from; and fifth, the very strong desire to make so much money within the shortest period. The implicit consequence is that people who would have been great entrepreneurs and employers of labour in the future end up becoming liability not only to themselves, but the family - parents, uncles, aunties, even brothers and sisters, and the nation. Yet, the daily cry is "unemployment". Who then must create employment? How must employment be created? What does the jobseeker has to offer in exchange for pay? These, are some of the questions begging for answers, which this work attempts but can not holistically provide.

This paper situates entrepreneurship opportunities in social and management sciences within the service offer of freelance salesmanship. The Thesis is that graduates of social and management sciences are readily selfemployable if properly orientated in the skills of selling. Even more to it, they are agents of job creation. Raising this consciousness among academics and students particularly becomes necessary because, again, the major problem of most manufacturing and service-providing organizations is not creating a job, rather, there is no money to pay salaries and allowances to those who may be engaged on the job due to lack of sales. Accordingly, Friedman (2004) opines that:

"The massive manufacturing
concerns of the early twentieth
century, which produced
tremendous numbers of business
machines, appliances, and cars,
hired salesmen in the hundreds
(and even thousands); and these
goods, all pushed by aggressive
salesmanship, distinguished the
American economy by their early
appearance and widespread
purchase".

Nigerian youths particularly graduates of social and management sciences, are, therefore, enjoined to embrace self-employment and see freelance salesmanship service as an unending job opportunity to explore, and not rendering to self-liability after the university education.

\section{ENTREPRENEURSHIP OPPORTUNITIES}

The first step to take by any person who desires successful entrepreneurship is seeking for opportunities. Experience has shown that opportunities are things people look at almost commonly around them but fail to see because they lack the ability to recognize them. To recognize opportunities means putting one's sensory organs into functionality and not dysfunctional because, not all that you look, you see; all you hear, you listen; all you taste, you test; all you smell, you tell the odour; or all you touch, you feel. It is therefore very important for an ambitious entrepreneur to learn translating the "not" into the "know" through interest building, conscious search, and continuous research. Thus, when you are able to see clearly, listen carefully, taste consciously, separate one odour from another, and rightly describe your feeling from what you touch, then ideas will begin to flow from every direction. One however, has to, at this point be very careful in articulating the inflow of ideas as not to get into profuse confusion, since, again, this may lead one into the temptation of paralyzing valid ideas by over analyzing them.

\section{ENVIRONMENTAL SCANNING}

The way to identify and tap into opportunity is to look and see what you have around you. Every environment provides its own 
opportunities. Again, the implication lies in that nosing around is very important. Environment describes the physical surroundings and things or events that happen in them - artificially or naturally, each presents some kind of opportunities. Thus, the Elements of physical artificial things / events include: locating of new project; war / crisis; economic; political; invention / discovery; commercialization / socialization; and others. On the hand, the physical natural things / events elements include: birth / death; earthquake I flood; epidemics I diseases; extractives / minerals; heat / cold; rain/sun; and / or others.

To achieve effective environmental scanning this paper suggests two simple, commonly adaptable strategic models: PESTLE and SWOT (Kachru, 2005) for identifying opportunities and weighing them against the various elements and events in the environment, as well as one's own ability to key into the resulting leverages. PESTLE stands for political, economic, social, technological, legal and environmental (ecological) factors. SWOT means strengths, weaknesses, opportunities and threats, offered by the environment. Both PESTLE and SWOT are tools available in social and management sciences for measuring entrepreneurship opportunities. The implications of these models for a freelance entrepreneur engaging in selling are two folds. First, conducting self analysis as an internal effort using the SW; second, for conducting external analysis, which the OT and PESTLE essentially project.

\section{CHALLENGES IN SOCIAL AND MANAGEMENT SCIENCES}

Strategic analysis is the key to opening entrepreneurship doors in social and management sciences. There are two dimensions to this namely, qualitative and quantitative. The qualitative view concerns with cognitive reasoning, while the quantitative approach attempts to translate the cognitive judgments into monetary measurement or financial equivalence.

i. Qualitative/cognitive. This domain essentially looks at entrepreneurship success from basic managerial processes of planning, organizing, controlling, motivating, monitoring, evaluating and reviewing of the inflows and outflows (employment and deployment) of resources, such as man, money, material, machine and information within time, to achieve good results. These activities are conducted in the continua of short-term, mediumterm and long-term. In practice, it is better to take it in the reverse form, this means that planning, which is the guiding post should be long-term, futuristic driven, and subsequently broken down into medium-term and short-term calendar for effective implementation. Consequently, longterm strategic planning should therefore, address among others, the following entrepreneurship questions:

- What is the prevailing economic situation at the national and, international or global level?

- What is the peculiar economic situation at the state level?

- What is the unique economic situation at the local and/or community level?

- What is the business orientation manufacturing or service?

- What is the market structure?

- What latent demands exist?

- What are the consumption and spending patterns of the people?

ii. Quantitative/financial. The challenges in this area border around such capital indices as return on investment (ROI), break-even point, net present value (NPV) and fixed and variable costs. Consequently, the strategic questions to be answered include, among others, the following:

- What is the cost of capital?

- What is the value of the currency in the exchange market?

- What is the cost of labour?

- What is the opportunity cost?

- What are the costs and ease of movement?

As necessary steps, these analyses will take the entrepreneur into the investment decision making proper. Such decision making again, calls for appropriate answers to the following among other questions:

- Where, should the business be situated?

- What size of land space is required for take off and/or expansion?

- What is the degree of friendliness or hostility of the local community?

- What are the culture and belief of the community people? 
- What is the history of relationships between the host community and its neighbors?

- What is government policy concerning the nature of business?

- What is the proximity to other businesses that may be sold to or bought from?

- What is the proximity to banking services and other ancillaries?

- Where can funding be sourced?

\section{SUSTAINABLE LIVING}

Abraham Maslow's theory defines human needs in five hierarchical orders from lowest to highest, starting with (i) physiological needs for shelter, clothing, sex, water, light and food; (ii) security needs for protection and safety; (iii) social needs for affiliation and interactions; (iv) ego needs for recognition, power, authority and higher personal status; and (v) the needs for selfactualization, utmost achievement and established personal uniqueness. As an exception to Maslow's postulation, the opportunity cost theory, holds that man must forego one thing in order to enjoy another. This lies in the fact that resources are scarce, therefore, it is not possible to have all that might be required at one time, since the available scarce resources must be distributed according to preferential schedule of needs to achieve effective demand.

Implicit from the foregoing is that sustainable living is a step-by-step approach to achieving one's desires through careful planning and decision-making in line with economic and environmental realities over time. The learning point is that in as mush as man's taste is directed by insatiability, there is no end to needs. This is precipitated by changes in the political, economic, social, technological, and ecological environments.

\section{OFFERING FREELANCE SERVICE}

McGregor's theory $X$ and theory $Y$ describe two sides of the human character. Theory X presupposes that man is born lazy and do not like to do much to earn desired better living. This view corroborates Taylor's natural soldiering and systematic soldiering, describing the unproductive nature of man either because he doesn't want to work or he deliberately slows down the pace of work in order to remain on the same job for as long as he earns pay, thereby working by the rule of thumb, unorganized. Theory $\mathrm{Y}$, contrary to theory $\mathrm{X}$ holds that man can do better if allowed to organize and coordinate himself with little or no directives, because he possesses the ability naturally to organize for play and leisure, similarly, he could engage himself in productive, economic activities investing the same time and energy. Again, this second view of McGregor is in tune with Taylor's scientific management approach, which believes that an organized man is a better productive man. First, for any person to be organized such one needs to develop self-consciousness or selfrealization. This brings upon the individual the challenge to personally conduct self-audit, with the attempt to providing answers to the following, among other questions:

- Who am I?

- What am I

- What knowledge and skills do I have?

- Can my skills be useful and for what?

- What, why, who, where, when and how do I want to be?

Answers to these questions can now become the guideposts for the individual's statement of intent for driving his vision and mission, setting goals, specific objectives, programs, tactics and actions taken.

\section{SALESMANSHIP}

An individual's skill, ability and capacity to persuade or convince another individual or a group, to accept a product or an idea that results in mutual benefit demonstrates his salesmanship. This implies that salesmanship is the art and act of developing and sustaining the platform for the offer and acceptance of goods and services between a seller and a buyer, who in turn become friends in business, and so, sharing/bearing the appellation "customer". Hence, both the buyer and the seller seek and give concessions to one another with the aim of building a long lasting relationship. The overriding objective of salesmanship, therefore, is to sell, meaning to make an effective exchange.

A person who wants to sell must first of all engage in selling. Selling involves a set of processes, techniques or tactics that must be consummated to achieve effective exchange of goods and / or services. Accordingly, the following are the simplified processes of selling an entrepreneur requires:

i. Self organization. Charity, it is said, begins at home. The home of a sales person is he, himself. The simple but difficult guiding question to provide 
answer to is: "am I ready"? Or "how ready am I"? Whichever way, a sales person must, to a very large extent, understand himself and get prepared both in mind and physical appearance to engage in the activities of selling. "Hence the seller must distinguish himself and his offering from those of others so that people will want, or at least prefer, to do business with him" (Theodore, 1983).

ii. Building acquaintance. For a sales person, knowing your product and the sales environment is as important as knowing yourself. The challenging questions therefore, among others are: what is the "in-and-out" or composition of the product offer I am taking to the prospects? It is important to note here, and not funny of course, that a prospect to the sales person is like a suspect to the policeman, because the prospect is a consumer/customer, and therefore, a potential buyer, in the same manner a suspect is anyone capable of committing a crime in the eyes of the police. Next question to provide answer to is: where are the potential consumers of the product? This poser puts the onus on the freelancer to begin to map out and group his potential customers into categories this is called market segmentation, and can be done by geographical grouping; demography - age, sex, height, complexion; or using such other factors as religion, social class, belief, income bracket, etc. How can they be reached? Here, the decision is made as to whether to use direct personal contact, or using a network of relationships/contacts. And when can they be reached?

iii. Prospecting / canvassing. This is an exploratory stage in the business of selling, particularly personal selling by searching for and making contacts oneon-one with potential buyers.

iv. Seeking appointment. Here, proper planning is called for, and the freelancer conducts survey on specific account prospects with follow up request for specific time to pay a business visit. An account prospect is a potential huge buyer who probably would continue to buy again and again over a long future period. In most cases, such a prospect is a senior executive who represents and could propose buying ideas to his organization, or even be in a position to make the buying decision. Booking an appointment to meet with senior executives flies through the desk of the secretary and or a personal assistant (PA). These categories of personnel including the gatemen and messengers are people to be handled with utmost care and tact, to have break- through.

v. Selling. This is the very core business of a freelancer where he employs innumerable amount of strategies and tactics. He comports himself with a great deal of psychology showing maturity, self confidence while instilling trust on the prospect. Among the key demonstrable features expected of a salesperson here include: compelling greetings with admirable smiles, seeking audience through self-introduction and watching out for the prospect's response or body language, secure comfortable space standing or offered a seat, following immediately introducing organization represented, the product and go into discussing product details with necessary demonstrations/displays, and securing order. It's important to note however, that all prospects don't respond the same way, depending on varying situations.

vi. Handling objections. Building on sound intelligence, the freelancer has to be very careful at handling objections raised by prospects. Objections are the probable vehement statements of attack and rejection of the salesperson's person or appearance, presentations and/or claims. This is of course, an acid test on the extent to which the freelancer was conscious and ready for questions. It is not a quarrel session rather, it offers another opportunity to the salesman to exhibit his ability to engage issues or confront challenges through the tools of effective communication - careful listening, composure, tactfulness, gestures and body language, among others. This experience occur in-between presentations at the selling stage.

vii. Obtaining order. The essence of selling is to make an effective exchange by getting order from prospects and turning them into customer. Achieving this feat could happen simultaneously at the selling phase and/or after objections 
have been settled. Again, it is very important to employ listening skill coupled with utmost carefulness, to record the order correctly with respect to quantity, type, price, delivery time, colour, size, and such other specifications or descriptions. Note worthily, the buyer will check against all these at delivery.

viii. Order delivery. One of the very first tests of honesty and relationship value measurement a buyer looks out for in an exchange transaction is the delivery promise made to him by a salesperson. While paying attention to all the details specified during order giving at delivery, the dateline the order is delivered is even more paramount to the buyer.

ix. Service delivery. Every buyer expects, and so, deserves fair treatment. Very little or nothing can gladden the heart of a buyer more than the perceived respect he gets from the seller especially a freelancer. Here, the buyer longs for courteousness, attention, help and solutions, explanations and advices, guidance, and assurances. These ingredients culminate in the beginning of strong relationship building between the freelancer and the client, that again, result in long lasting confidence and trust.

x. Relationship management. The very essence of doing business profitably and attaining sustainability is building clientele. Leveraging on the service delivery offer, a freelancer needs to keep in with major accounts and high turnover buyers. Major accounts are those who buy in huge quantity and money, while high turnover buyers are those who buy frequently, that could translate into big quantity and big money value on the long run. This puts a responsibility on the freelancer to follow on by collecting, establishing and maintaining a databank of his clients, so that he occasionally, gets to them through personal visits, telephone calls, text messages, email messages, and social media groups. This aims to know how the clients are fairing with the product purchased, and to provide advice on what to do if there is any problem. It's a public relations bond which builds the relationship beyond just being business friends or customers, to the extent of becoming family friends.

\section{STRATEGIES FOR FREELANCE ENTREPRENEURIAL SELLING}

Today's experts were yesterday's novices. The beginning of a successful freelance entrepreneurial selling is to start as a neophyte. It's no exaggeration saying no matter how much formal education acquired, selling is a skill, though natural, but still need to be developed through training and practical encounter. The new entrant into the business wants to find answers to the questions of where and how to start it. To become a self-employed freelance entrepreneur, the following are prescriptively, important steps to take:

a. Establishing contact address. Having appreciated the fact of being ready for the stride, a freelance entrepreneur may primarily choose to start from home since he does not hold any big stock for which warehousing facilities may be required. Where necessary, his stock carriages are light sample products and or brochures/flyers. This instills the thinking of living in a good residential area where houses bear clear street numbering. Better still, one could identify a family friend or relative already in business and seek permission to make use of his place as a contact for a time. The aim is to have better description for the purposes of easy contact and printing of business call cards and other documents.

b. Packaging $\mathrm{CV} /$ personal resume. The first instrument to introduce oneself and obtain confidence is the Curriculum Vitae $(\mathrm{CV}) /$ personal resume or profile. This document speaks a lot about the owner on his behalf. The document provides the privilege of giving such details as one's full name, sex, date and place of birth, home town, local government of origin or county, state and country, schools attended with dates as well as academic certifications, professional qualifications, narration of types of job done in the past and/or being done now, personal life goal and objective, special skills possessed, among others and concluding with at least three referee names with their contacts. The salient import of this is that if you can't sell yourself, you can't sell a product; the essence is to enable the recipient 
conduct a fair assessment of you in your absence or even sometime in your presence and form decisive opinion or take a decision. Thus, there is a need for continuous improvement in the preparation and presentation of one's CV.

c. Identifying organizations. Here, the potential freelancer or self employer conducts search and screening of organizations or companies he would like to sell for. It is noteworthy to mention that the organizations are at this point also, being assessed by stakeholders they might never or least considered relevant to their business. Thus, the applicant should be concerned about such elements as the company's offers in terms of goods, services, prices, distribution efforts, product presentation/packs, image, reputation and many other features. Hence, organizations must build very sound public relations platform to enlist stakeholders' confidence.

d. Selling/marketing ones' self. At this point it is important that a potential freelancer markets or sells himself to those who may require his services. This effort could be achieved either through personal contacts or posting of $\mathrm{CV}$ or both.

The resulting implications for self-reliance among other apart from general exposure to the world of business include self-realization and confidence building, development of the knowledge of various products and brands.

\section{CONCLUSION AND RECOMMENDATIONS}

Graduates of social and management sciences should be trained and deeply immersed with salesmanship orientation to become job creators and providers and not job seekers all the time, thereby getting unemployed. Selfemployment, through engagement in freelance salesmanship is a worthwhile entrepreneurial undertaking. Most manufacturing and serviceproviding organizations are challenged by not having money to pay salaries and allowances to those who may be engaged on the job due to lack of sales rather, creating a job, is not the issue. Raising this consciousness among academics and students particularly becomes necessary. Nigerian youths particularly graduates of social and management sciences, are, therefore, enjoined to embrace self-employment and see freelance salesmanship service as an unending job opportunity to explore, and not rendering to self-liability after the university education.

\section{REFERENCES}

Duru, M., 2011. Business and Management Review 1(1): 41-48.

El-Sayed, J., El-Sayed, M and Beyerlein, S., 2010. Validation of hybrid program design through a stakeholder survey. International Journal of Process Education, 2, 3-10.

Friedman, W. A., 2004. Birth of a Salesman the Transformation of Selling in America Cambridge: Harvard University Press.

Kachru, U., 2005. Strategic Management Concepts and Cases, New Delhi: Excel Book.

Okwelle, P. C., 2013. Appraisal of Theoretical Models of Psychomotor Skills and Applications to Technical Vocational Education and Training (Tvet) System in Nigeria Journal of Research and Development, 1, (6): 25.

Theodore, L., 1983. The Marketing Imagination New York: The Free Press.

Uwaifo, V. O., 2010. Technical education and its challenges in Nigeria in the 21st century. International NGO Journal, 5(2), 040 044. 
